Assessing pre-service teachers' beliefs about the role of the library media specialist

Wolcott, Linda L;Lawless, Kimberly A;Hobbs, Deborah

International Association of School Librarianship. Selected Papers from the ... Annual Conference; 1999;

Education Database

pg. 155

\title{
Assessing Pre-service Teachers' Beliefs About the Role of the Library Media Specialist
}

\author{
Linda L. Wolcott, Ph.D \\ <wolcott@cc.usu.edu> \\ Associate Professor \\ Department of Instructional Technology, Utah State University \\ United States of America
}

Kimberly A. Lawless, Ph.D

Assistant Professor

Department of Instructional Technology, Utah State University

United States of America

\section{Deborah Hobbs, Ph.D.}

\section{Associate Professor \\ Department of Elementary Education, Utah State University United States of America}

The revision of Information Power (1998) focuses on building partnerships for greater student learning. While not a radical departure from the previous edition (1988), the recent document emphasizes both greater collaboration and leadership and increased involvement with the technologies of information and learning. This study set out to determine whether teacher education programs were preparing tomorrow's teachers to expect and accept the redefined role of the school library media specialist. It involved the development and the administration of a scale to assess pre-service teachers' beliefs about the role of the school library media specialist. The results of the pilot study reported here are preliminary but suggest that while pre-service teachers distinguish three distinct sets of functions they place more emphasis on those functions associated with information access and delivery than on those related to learning and teaching. Further, pre-service teachers do not appear to understand the role areas of learning/teaching and program administration.

\section{Introduction}

The recent update of Information Power (1998) emphasizes three major areas of the library media specialist's role: learning and teaching, information access and delivery, and program administration. This restatement of the original roles of teacher, information specialist, and 
instructional consultant, is set in a context of collaboration, leadership. and technology - the unifying themes for partnerships in the information age. The new guidelines introduce the Information Literacy Standards for Student Learning as the foundation for effective library media programs. The Standards firmly establish the library media specialist as an essential partner in fostering student learning.

We asked ourselves whether and to what extent the envisioned roles of the library media specialist match the conception held by pre-service teachers. Do teachers in training share common ground with the drafters of Information Power? Are pre-service teachers' beliefs about the role of the library media specialist such that they would be accepting of the newly defined roles? Would their beliefs predispose them to work in partnership with library media specialists in their expanded role?

The research described in this paper sets out to explore pre-service teachers' beliefs about the library media specialist's role. Specifically, the goal of the study was to ascertain the degree of awareness that pre-service teachers have of the three major roles of the library media specialist as delineated in Information Power: Building Partnerships for Learning. Responses to this inquiry can help us determine whether teacher education programs are adequately addressing the role of the library media specialist and library media programs in the curriculum. Further, knowledge of pre-service teachers' beliefs can provide us with strategies for building relationships between the library media specialist and novice teachers.

\section{Methodology}

To assess pre-service teachers' beliefs about the role of the library media specialist, we undertook the development of a scale. We began by identifying items derived from the principles and goals detailed under each of the three major roles in Information Power. We conducted a content analysis of the principles and goals, a process that involved separating, categorizing, and coding individual concepts. By sorting and comparing the statements within each code category, we identified major themes and elements, combined similar items, and eliminated redundant ones. Further, we selected those items that described functions within a role, rather than those that stated a specific task which library media specialist performed or a behavior they exhibited. The process yielded a list of 45 preliminary items.

Our next step involved matching each item to one of the three role areas: learning and teaching, information access and delivery, and program administration. To confirm whether our categorization of items aligned with the role constructs, we collected judgmental validity evidence from graduate students in the Department of Instructional Technology at Utah State University (USA). Using conceptual definitions for each of the hypothesized constructs the students assigned each item to one of the three categories based on these definitions. We ran frequency analyses on the student responses to determine the degree of agreement among item assignments. As a result of the analysis, we collapsed two categories, refined the definitions, and reworded several items to better align them with the construct category. After the revision, we repeated the process with a separate group of undergraduate education majors. The subsequent analysis yielded a list of 43 items. 
With confidence in the conceptual definitions and the operational ability of the items, we prepared the scale using a Likert response ranking, ranging from $\mathrm{A}$, representing strongly disagree, to E, representing strongly agree. We then administered a pilot test of the scale to approximately 300 pre-service teachers enrolled in their junior or senior year at one of three teacher education programs. The institutions represented included a large eastern university, a mid-sized western university, and an eastern teacher education college. Subjects were asked to indicate the degree to which they agreed that each of the items represents a role that a school library media specialist should perform. A total of 262 responses were returned; 63, 177, and 22 from the participating institutions, respectively. The sample consisted predominantly of female students $(91 \%)$ enrolled in their senior year $(58.8 \%)$. The average age of subjects was 23 , and their average self-reported GPA was 3.5.

Responses to the pilot scale were entered into a spreadsheet file using Microsoft Exce198 and subsequently imported into the statistical package SPSSTM. Frequency distributions, means, and standard deviations were obtained for each of the items. To determine the reliability of the scale, an exploratory factor analysis was conducted for all scores. Prior to performing the calculations, data were screened for outliers as well as missing and miscoded data.

\section{Results/Findings}

Three factors emerged from the exploratory factor analysis. The factors identified by the preservice teachers account for $49.5 \%$ of the variance and closely correspond to the three hypothesized categories. Based on the items that loaded on them, we labeled the resulting factors: curriculum and instruction, resource provision and guidance, and library media center (LMC) administration. With 20 items loading on it, resource provision and guidance was the factor with the highest reliability $(\alpha=.96)$ and the highest mean score (4.41). The second highest factor with a mean of 4.21 and an alpha of .88 consisted of twelve items relating to curriculum and instruction. The third factor was comprised of nine items associated with library media center administration; the mean was 3.73 and $\alpha=.89$. Tables 1,2 , and 3 list the items that loaded on each of the three factors. 
Table 1. Items Loading on Factor 1: Resource Provision and Guidance

\begin{tabular}{|c|c|c|}
\hline & Mean & $\begin{array}{l}\text { Standard } \\
\text { Deviation }\end{array}$ \\
\hline 1. teach students how to conduct research & 4.09 & 91 \\
\hline $\begin{array}{l}\text { 5. provide information resources appropriate to students' information } \\
\text { needs and learning tasks }\end{array}$ & 4.58 & .77 \\
\hline $\begin{array}{l}\text { 6. provide information resources that represent diverse points of } \\
\text { view }\end{array}$ & 4.38 & .85 \\
\hline $\begin{array}{l}\text { 8. create an atmosphere that encourages use of the library media } \\
\text { center }\end{array}$ & 4.70 & .75 \\
\hline $\begin{array}{l}\text { 9. match the information needs and interests of individual users with } \\
\text { appropriate library resources }\end{array}$ & 4.45 & .79 \\
\hline $\begin{array}{l}\text { 10. integrate library media competencies (i.e., skills in using } \\
\text { information and technology) into the curriculum and } \\
\text { instructional activities }\end{array}$ & 4.22 & .87 \\
\hline $\begin{array}{l}\text { 12. develop a collection of information resources that supports } \\
\text { instruction and individual interests }\end{array}$ & 4.44 & .79 \\
\hline $\begin{array}{l}\text { 13. evaluate the effectiveness of library media resources, services, } \\
\text { and programs }\end{array}$ & 4.50 & .84 \\
\hline $\begin{array}{l}\text { 14. teach students information literacy concepts and skills (i.e., how } \\
\text { to locate, evaluate, and use information) }\end{array}$ & 4.45 & .88 \\
\hline 16. ensure access to a wide range of information and ideas & 4.51 & .83 \\
\hline $\begin{array}{l}\text { 18. provide access to information resources outside the library media } \\
\text { center (e.g., through interlibrary loan, electronic networks, and } \\
\text { resource sharing }\end{array}$ & 4.31 & .87 \\
\hline $\begin{array}{l}\text { 20. provide information resources to accommodate a wide range of } \\
\text { abilities, learning styles, and information needs }\end{array}$ & 4.38 & .85 \\
\hline $\begin{array}{l}\text { 22. provide information resources and adaptive technologies for } \\
\text { students with disabilities or specials needs }\end{array}$ & 4.34 & .89 \\
\hline $\begin{array}{l}\text { 23. promote the library media center, its programs and services as } \\
\text { essential components of the school's instructional program }\end{array}$ & 4.48 & .83 \\
\hline 24. plan for the on-going development of the library media program & 4.49 & .83 \\
\hline $\begin{array}{l}\text { 29. encourage students to read, view, and listen for enjoyment as } \\
\text { well as for information }\end{array}$ & 4.48 & .87 \\
\hline $\begin{array}{l}\text { 33. teach ethical behaviors with respect to the use of information and } \\
\text { technologies (e.g., compliance with copyright regulations and } \\
\text { responsible use of the Internet) }\end{array}$ & 4.34 & .87 \\
\hline $\begin{array}{l}\text { 34. develop policies and procedures for use of the library media } \\
\text { center and it materials }\end{array}$ & 4.44 & .85 \\
\hline 38. organize library resources to facilitate access and use & 4.54 & .80 \\
\hline $\begin{array}{l}\text { 41. provide information resources in a wide range of formats (e.g., } \\
\text { traditional as well as computerized resources) }\end{array}$ & 4.41 & .83 \\
\hline
\end{tabular}


Table 2. Items Loading on Factor 2: Curriculum and Instruction

\begin{tabular}{|c|c|c|}
\hline & Mean & $\begin{array}{l}\text { Standard } \\
\text { Deviation }\end{array}$ \\
\hline 3. facilitate teaching of the school's curriculum & 3.46 & 1.01 \\
\hline 7. participate in developing school curriculum & 3.50 & 1.00 \\
\hline 11. identify needs of the school community & 3.74 & .87 \\
\hline 17. teach students how to be independent learners & 3.71 & 1.06 \\
\hline 19. plan instructional activities with teachers & 3.83 & .94 \\
\hline 21. create instructional materials for teaching and learning & 3.77 & 1.02 \\
\hline 25. guide teachers in the effective design of instruction & 3.41 & 1.06 \\
\hline 26. support the concept of the intellectual freedom of information & 3.78 & .97 \\
\hline 35. foster collaborative inquiry as well as individual inquiry & 3.99 & .90 \\
\hline 39. help students develop life-long learning skills & 4.04 & 1.07 \\
\hline 40. oversee the allocation of financial resources & 3.67 & .99 \\
\hline 42. help students develop critical thinking skills & 3.86 & 1.02 \\
\hline
\end{tabular}

Table 3. Items Loading on Factor 3: LMC Administration

\begin{tabular}{|c|c|c|}
\hline & Mean & $\begin{array}{l}\text { Standard } \\
\text { Deviation }\end{array}$ \\
\hline 4. serve as a member of the school's administrative team & 3.82 & .98 \\
\hline $\begin{array}{l}\text { 15. communicate program needs, goals, and accomplishments with } \\
\text { school administrators }\end{array}$ & 4.13 & .92 \\
\hline $\begin{array}{l}\text { 27. develop programs through the library media center that reflect } \\
\text { the mission, goals, and objectives of the school }\end{array}$ & 4.16 & .93 \\
\hline 28. provide leadership in using technology for teaching and learning & 4.31 & .83 \\
\hline $\begin{array}{l}\text { 30. coordinate the purchase of materials including hardware and } \\
\text { software for the library media center }\end{array}$ & 4.42 & .88 \\
\hline $\begin{array}{l}\text { 31. help students develop media literacy skills (i.e., how to analyze } \\
\text { mass media) }\end{array}$ & 4.23 & .91 \\
\hline $\begin{array}{l}\text { 32. communicate with parents and other members of the community } \\
\text { about the library media center }\end{array}$ & 4.07 & .90 \\
\hline $\begin{array}{l}\text { 36. manage the use of the library media center facilities and } \\
\text { resources }\end{array}$ & 4.47 & .87 \\
\hline $\begin{array}{l}\text { 37. collaborate with district personnel in providing library media } \\
\text { services }\end{array}$ & 4.30 & .81 \\
\hline
\end{tabular}

Only two of the 43 items did not load on any of the three factors; these were items 2 , supervise the library media center staff, and 43, train the school staff in the use of information resources and technology. The overall scale reliability was high, reporting a Cronbach's alpha of .96 when subjected to principal axis factoring with equamax rotation.

On which of the 43 items was there the highest agreement? The pre-service teachers most strongly agreed that the library media specialist should create an atmosphere that encourages use of the library media center $(79.8 \%)$, provide information resources appropriate to students' information needs and learning tasks $(68.2 \%)$, and organize library resources to facilitate access and use $(67.2 \%)$. Table 4 lists the ten items with which the subjects most strongly agreed. With two exceptions, these items are associated with Factor 1, resource provision and guidance. 
Table 4. Items with Strongest Agreement

Percent

Item

8. create an atmosphere that encourages use of the library media center

79.8

5. provide information resources appropriate to students' information needs and learning tasks

68.2

38. organize library resources to facilitate access and use

29. encourage students to read, view, and listen for enjoyment as well as for information

67.2

65.3

13. evaluate the effectiveness of library media resources, services, and programs

64.8

16. ensure access to a wide range of information and ideas

36. manage the use of the library media center facilities and resources

24. plan for the on-going development of the library media program

63.7

23. promote the library media center, its programs and services as essential components of the 63.4 school's instructional program

14. teach students information literacy concepts and skills (i.e., how to locate, evaluate and use 63 information ) 30. coordinate the purchase of materials including hardware and software for the library media 61.3
center

34. develop policies and procedures for use of the library media center and its materials

The majority of subjects were in agreement with all of the items; there were no items on which the majority of subjects either disagreed or strongly disagreed. The largest percent of disagreement (20\% combined disagree and strongly disagree) was in response to the statement that the library media specialist should guide teachers in the effective design of instruction. The lowest means occurred with items that loaded on Factor 2, dealing with learning and curriculum.

\section{Conclusions}

The results of the factor analysis conducted on the pilot administration of the scale validate it as a measure of pre-service teachers' beliefs about the role of the library media specialist. The factors that emerged align with the three major role areas outlined in Information Power. However, despite a close correspondence between the factors and the role areas, the distribution of items across the three factors differs somewhat from our categorization of items derived from Information Power. Pre-service teachers appear to see the role areas a little differently. For example, Factor 1 focuses on providing resources but also encompasses administrative functions associated with information access and with instruction and guidance in the use of resources. Factor 2 emphasizes functions relating to curriculum and facilitating instruction; there appears to be less involvement on the part of the library media specialist in directly teaching students and teachers in the use of resources and technology. Functions pre-service teachers associate with Factor 3 are, with one exception, administrative but the scope of the factor is limited. Subjects associated a number of clearly administrative functions such as planning and public relations with Factor 1. Subjects in the study do not appear to understand the role areas of learning/teaching and program administration.

Analysis of the individual items provides further evidence of this perception. The items on which subjects expressed strong agreement are primarily those that loaded on Factor 1, resource provision and guidance. Few items related to Factor 3, LMC administration, and none associated with Factor 2, curriculum and instruction, are among the first ten or even 20 items on which 
students indicated strong agreement. The items receiving the lowest ratings are those that deal with teaching and collaborating with teachers in developing curriculum and instruction.

What does this suggest about pre-service teachers' conception of the library media specialist role? According to the data, we conclude that the pre-service teachers closely identify the library media specialist with the more traditional "librarian" role. The resource manager and information provider functions are closely linked and key aspects in their perception of the library media specialist role. We are gratified to find an acknowledgement of the administrative functions. However, we are concerned that items we associate with the learning and teaching area and those that emerged as Factor 2, are poorly represented among the functions that the preservice teachers believe are integral to the role of the library media specialist.

In summary, pre-service teachers distinguish three distinct sets of functions. Among the role areas, they place more emphasis on those associated with information access and delivery than on those related to learning and teaching. Given the subjects' responses to individual items, we conclude that they do not share the vision of the library media specialist as a collaborative partner and leader in instruction and technology espoused in Information Power.

Further development of the instrument will expand our understanding of pre-service teachers' beliefs as we administer the scale to larger sample and apply qualitative approaches to identify alternative role conceptions. Additional analysis will be conducted to identify correlations among individual items and comparisons among groups representing different teacher education programs and stages of academic preparation.

Writers of Information Power envisioned collaboration and leadership in instruction and technology as hallmarks of the library media specialist's role. Results of the pilot study of the pre-service teachers' belief scale suggest that in order to build partnerships for student learning, the education community should:

- widely disseminate Information Power and The Information Literacy Standards for Student Learning to the education community, especially to classroom teachers and teacher educators;

- raise awareness in teacher education courses of the broader role of the library media specialist;

- involve pre-service teachers in field experiences and student teaching with library media specialists who exemplify the principles of Information Power;

- model collaboration by partnering with library media educators in teacher education programs; and

- promote The Information Literacy Standards for Student Learning along with the core standards of other disciplines. 


\section{Notes}

1 This study was funded by a 1998 AASL/Highsmith Research Grant.

\section{References}

Information Power: Building Partnerships for Learning. (1998). Chicago: American Library Association. 